Jurnal Ilmiah "Kreatif" Vol. XII No. 2 Juli 2015

"Jurnal Studi Pemikiran Pendidikan Agama Islam"

\title{
KONSEP PENGEMBANGAN PENDIDIKAN ISLAM MODERN
}

Oleh: Ihlas *

\begin{abstract}
Abstrak
Artikel ini bertujuan mengetahui konsep pengembangan pendidikan Islam. Selanjutnya tulisan ini diharapkan bermanfaat bagi pengelola lembaga pendidikan Islam dalam mengembangkan nilai-nilai Islam dalam dunia pendidikan yang berhaluan modren. Artikel ini menggunakan metode kajian kepustakaan (library recearch). Simpulan pada artikel ini pertama, penyelenggaran pendidikan Islam harus kembali menjadikan Islam sebagai panji dan acuan cita ideal pendidikan Islam. Kedua, pendidikan Islam harus berorietasi pada kualitas bukan populis. Ketiga, pendidikan Islam perlu merumuskan pilot project, agar arah dan target pendidikan Islam dapat tercapai, Keempat, perlunya dunia pendidikan Islam untuk melakukan upaya reformasi dari segala komponen baik sumber daya manusia (SDM), sistem manajemen maupun kurikulumnya dalam bingkai integralistik. Dan kelima, perlunya intergrasi kelimuan antara pendidikan umum dan pendidikan Islam, agar orientasi ukhrawi dan duniawi sama-sama dapat tercapai.
\end{abstract}

Kata Kunci: Reorientasi, Pendidikan Islam, Pembaruan, Integrasi, Pembebasan

\section{Pendahuluan}

Konferensi internasional pertama kali tentang pendidikan Islam di selenggarakan di Makkah pada tahun 1977, yang merumuskan tujuan pendidikan Islam sebagai berikut.

"Pendidikan bertujuan mencapai pertumbuhan kepribadian manusia yang menyeluruh secara seimbang melalui latihan jiwa, intelek, diri manusia yang rasional; perasaan dan indera. Karena itu pendidikan harus mencakup pertumbuhan manusia dalam segala aspeknya: spiritual, imajinatif, fisik, ilmiah, bahasa, baik secar individual maupun secara kolektif, dan mendorong semua aspek ini kearah kebaikan dan mencapai kesempurnaan. Tujuan akhir pendidikan Muslim terletak pada perwujudan ketundukan

\footnotetext{
*Dosen Tetap Institut Agama Islam (IAI) Muhammadiyah Bima email: ichlash.pascaums13@gmail.com
} 
Jurnal Ilmiah "Kreatif" Vol. XII No. 2 Juli 2015

"Jurnal Studi Pemikiran Pendidikan Agama Islam"

sempurna kepada Allah baik secara pribadi, komunitas, maupun seluruh ummat manusia"1

Konferensi itu menghendaki adanya pembaruan terhadap sistem pendidikan Islam. Pembaruan memiliki kesamaan arti dengan kata modernisme, yang bermakna keterbukaan untuk menerima hal-hal baru dan ikhtiar dalam melakukan upaya perubahan. Baik itu tentang paradigma keilmuan, pemikiran, maupun gagasan yang mengarah kepada peningkatan mutu peradaban hidup dan pendidikan.

Ide pembaruan lahir sejak beberapa abad yang lalu sebagai ikhtiar kebangkitan pendidikan Islam sebagai perlawanan atas tekstualisasi Al-Qu'an, konservatisme, dan kekakuan dalam menerima perubahan zaman.

Gagasan mengenai pembaruan pendidikan Islam mempunyai keterkaitan dengan gagasan tentang "modernisme" pemikiran dan institusi Islam secara keseluruhan. Pembaruan atau modernisme pendidikan Islam merupakan pra-syarat bagi kebangkitan kaum muslim di masa modren. Karena itu pemikiran dan kelembagaan pendidikan Islam haruslah dimodernisasi, sederhananya diperbarui sesuai dengan kerangka "modernitas". Sebab mempertahankan pemikiran kelembagaan Islam "tradisional" hanya akan memperpanjang nestapa ketidakberdayaan kaum Muslim dalam berhadapan dengan kemajuan dunia modern. ${ }^{2}$

Pembaruan dalam dunia Islam sudah dimulai oleh para tokoh cendekiawan Islam seperti Ibnu Taimiyah, Al-Afghani, Muhammad Abduh, , Rasyid Ridha, Fajlur Rahman, dan pemikir Islam lainnya. Buah pemikiran tokoh-tokoh Islam ini mempunyai pengaruh yang besar pada perubahan pola pendidikan Islam dan cara pengamalannya. Memperbarui pemahaman keagamaan (keislaman) yang masih bersifat ortodoks (kolot) dan dikotomis.

Pemikirannya Fazlur Rahman (1919) yang menyuguhkan analisis perkembangan pendidikan Islam dan merumuskan alternatif metodologi pemikiran ke-Islaman sebagai rumusan jalan keluar dari seluruh kritisisme atas sejarah pemikiran ke-Islaman yang cenderung konservatif. Untuk mewujudkan masyarakat Islam sebagi kompetitor di pentas global memerlukan sarana penunjang. Sarana penunjang yang dimaksud tiada lain adalah perubahan pada sistem kelembagaan pendidikan Islam. Sistem pendidikan harus terlebih dahulu dimodernisasi atau diperbarui.

${ }^{1}$ Azyumardy Azra, Pendidikan Islam-Tradisi dan Modernisasi Menuju Milenium Baru. (Jakarta: Logos Wacana Ilmu, 2000), 57

${ }^{2}$ Ibid, 31 
Jurnal Ilmiah "Kreatif" Vol. XII No. 2 Juli 2015

"Jurnal Studi Pemikiran Pendidikan Agama Islam"

Fazlur Rahman meniscayakan bahwa rakyat di negara Islam mempunyai kekuasaan untuk menerjemahkan teks Qur'an guna merancang undang-undang untuk kemaslahatan ummatnya. "Kedaulatan Allah" dalam kiblatnya tidak bisa dipandang sebagai sesuatu yang absolut dan kaku. Sebab di dalam Al-Qur'an memiliki konsekwensi berupa perlunya suatu kerangka pembaruan dalam rangka mengungkap ajaran-ajaran moral yang ada di dalamnya. ${ }^{3} \mathrm{Al}$-Qur'an bukanlah kitab undang-undang melainkan kitab yang berisi ajaran-ajaran dan petuntuk Tuhan (Allah) untuk kepentingan umat manusia yang belaku di segala zaman dan peradaban. Ajaran-ajaran ini masih harus diberi bentuk segar dalam pengertian legislasi. Dalam proses pembentukan hukum, prinsip ijtihad dan ijma' memiliki peran penting. Dua-duanya memberikan kepastian yang senantiasa diperlukan dalam hukum dan juga faktorfaktor yang memungkinkan adanya perubahan dan dinamika hukum sehingga itu dapat mencerminkan gagasan-gagasan perubahan, kemajuan dan perkembangan masyarakat yang educatif.

Sejalan dengan gagasan KH. Ahmad Dahlan (1902), bahwa pembaruan pendidikan Islam harus diintegrasikan dengan pendidikan Umum. Posisi pendidikan Islam harus disejajarkan dengan pendidikan umum dan dalam penyelenggaraannya tidak ada yang namanya dikotomi. Spesifikasi pembaruan dalam gagasan beliau adalah pemurnian tauhid baik itu tauhid pribadi maupun tauhid sosial juga harus diajarkan di sekolah umum. Bentuk tauhid pribadi adalah memberantas TBC (tahayyul, bidah dan churafat). Sedangkan tauhid sosial adalah mengimplementasikan dakwah amar ma'ruf nahyi munkar dan mengaktualisasikan teologi al-Ma'un dan ayat-ayat al-Qur'an untuk mewujudkan masyarakat Islam yang sebenar-benarnya (baca: $\mathrm{KH}$. Ahmad Dahlan).

Sementara Malik Fadjar sebagai tokoh dinamisator pendidikan Islam diera 70-an, menghendaki pembaruan pendidikan Islam dengan membangun keterpaduan antara pendidikan umum dengan pelembagaan secara resmi. Dengan harapan terbentuknya out put pemikiran yang sinergis, unggul secara intelektual dan memiliki moralitas yang bagus. ${ }^{4}$

Gagasan utama Malik Fadjar dalam pembaruan pendidikan Islam adalah menghilangkan pola pesantren yang cenderung konservatif dan perguruan tinggi yang berhaluan liberal. Seperti Instutut Agama Islam Negeri (IAIN) yang banyak memproduk para cendekia tapi banyak

3 Abdul Munir Mulkhan,. Menggagas Pesantren Masa Depan, (Yogyakarta: Qolam, 2003), 23

${ }^{4}$ Malik Fadjar, Holistika Pemikiran Pendidikan. (Jakarta: Raja Grafindo Persada, 2005), 24 
Jurnal Ilmiah "Kreatif" Vol. XII No. 2 Juli 2015

"Jurnal Studi Pemikiran Pendidikan Agama Islam"

yang berpikir liberal. Sedangkan yang pesantren unggul secara agama dan moral namun lemah dari segi intelektual. ${ }^{5}$ Malik Fadjar mencoba "mengawingkan" dua pola pendidikan tersebut agar kedua-keduanya dapat menyatu secara massif. ${ }^{6}$

Potret pemikiran Malik Fadjar dapat dilihat dari kebijakannya terhadap lembaga pendidikan Islam di Indonesia. Dari banyak referensi, hampir semua lembaga-lembaga pendidikan yang pernah dipimpinnya mencapai kualifikasi academic excellence dan kompetitif advantage di era global ini. ${ }^{7}$ Pemikiran beliau yang prinsip tentang pendidikan Islam yakni mengenai integritas keilmuan. Melakukan dekonstruksi terhadap realitas keilmuan yang bersifat dikotomis.

\section{Reorientasi Pendidikan Islam}

Malik Fadjar salah satu dari banyak tokoh pendidikan Islam memberikan kritikan terhadap pendidikan yang diterapkan pada lembaga pendidikan Islam seperti pondok pesantren yang monoton pada agama dan sangat berbeda dengan model sekolah Negara haruslah dirubah dengan sistem pendidikan terpadu. Yakni memadukan ilmu agama dengan sistem pendidikan umum ${ }^{8}$ Dengan demikian lembaga pendidikan Islam akan menghasilkan out put yang matang dalam agama dan memiliki semangat patriotisme.

Begitu juga dengan perguruan tinggi harus menerapkan pola pendidikan yang menggabungkan antara pendidikan umum dengan pendidikan Islam dengan mengadopsi pendidikan model Barat. Karena sistemnya dipandang "yang terbaik" dan disempurnakan dengan penambahan mata pelajaran kearifan lokal (local wisdom). Dengan kata lain, Ia berusaha untuk mengislamkan berbagai segi kehidupan yang tidak Islami. Umat Islam tidak diarahkan kepada pemahaman "agama mistis" melainkan menghadapi dunia secara realitis.

Sebagai sarana dalam melakukan upaya pembaruan atau mereorientasi pendidikan, kita dapat menjadikan Muhammadiyah dan Nahdatul Ulama (NU) sebagai obyek kajiannya khusus pada reorientasi wawasan pendidikan Islam di Indonesia. Sebab kedua organisasi kemasyarakatan (ormas) Islam tersebut merupakan ormas terbesar di Indonesia dan cukup representatif untuk dijadikan sebagai bahan analisis dalam kerangka pembaruan pendidikan yang ada di negeri ini.

${ }^{5} \mathrm{Ibid}, 13$

${ }^{6} \mathrm{Ibid}, 15$

${ }^{7}$ Ibid, 3

${ }^{8}$ A, Mujib, dkk, Intelektualisme Pesantren, (Jakarta; Diva Pustaka, 2003), 
Jurnal Ilmiah "Kreatif" Vol. XII No. 2 Juli 2015

"Jurnal Studi Pemikiran Pendidikan Agama Islam"

Apakah yang menjadi factor penentu (determiner), sehingga Muhammadiyah (1912) dan NU (1926) mampu mempertahankan gerakan dan perannya dalam elan sejarah yang begitu panjang hingga kini? Di tengah ormas lain timbul tenggelam, NU dan Muhammadiyah terus berkembang dalam memacu diri berkreatifitas mengembangkan pendidikan menurut caranya masing-masing. NU menggagas pendidikan pola pesantren dan Muhammadiyah mencoba mengembangkan pendidikan pada lembaga-lembaga umum seperti SD, SMP, SMA dan perguruan tinggi.

Faktor determinant itu barangkali pada kepiawaian kedua gerakan Islam itu dalam mengkombinasikan dua hal. Pertama, keduanya konsisiten berpegang pada tradisi keislaman, yaitu keyakinan pada doktrin yang tertuang dalam al-Qur'an dan Sunnah, serta perbedaan paham yang dikembangkan sebagai interpretasi dirinya. Kedua, keduanya memiliki sikap positif terhadap perubahan yang terjadi di sekitarnya, sekalipuan dalam tingkat responsivitas yang berbeda pada setiap kasusnya. Hal ini tercermin pada langkah-langkah yang ada, baik persoalan politik, ekonomi, maupun sosial kermasyarakatan. ${ }^{9}$

Agaknya ideologi gerakan Islam itu terproyeksikan juga tatkala keduanya mengarahkan gerakannya pada sektor pendidikan. Hal itu terlihat pada perbedaan pemilihan bentuk maupun substansi pendidikan yang di selenggarakan. Namun belakangan ini keduanya dalam arti positif sering melakukan Over Lapping. Contohnya, NU pada pondok Pesantren, sementara Muhammadiyah pada pendidikan umum. Tetapi Buya Syafi'ie Ma'arif, memberikan satu pertanyaan untuk kedua gerakan Islam tersebut, "Apakah sistim pendidikan yang dikembangkan oleh kedua gerakan Islam tersebut selama ini sudah dipandang memadai untuk membawa bangsa Indonesia yang maju dan berwibawa secara moral dan intelektual?". ${ }^{10}$

Gagasan tentang reorientasi serta rancang pendidikan Islam agar ada perubahan yang berarti di masa depan dalam rangka mewujudkan pendidikan islam yang bermartabat untuk peradaban hidup yang berakarakter melalui pola pendidikan antara lain;

\section{Menjadikan Islam Sebagai Acuan Cita Ideal}

Islam harus dijadikan sebagai acuan cita ideal pendidikan Islam. Sekalipun kedua gerakan Islam (NU dan Muhammadiyah) tidak secara eksplisit menyebutkan Islam sebagai bagian dari

\footnotetext{
${ }^{9}$ Abdul Munir Mulkhan, Menggagas Pesantren..., 32

${ }^{10}$ Abdul Malik Fadjar, Reorientasi Pendidikan..., 67
} 
Jurnal Ilmiah "Kreatif" Vol. XII No. 2 Juli 2015

"Jurnal Studi Pemikiran Pendidikan Agama Islam"

namanya, namun semua tahu bahwa keduanya berstatus sebagai organisasi masa Islam (ormas) serta berperan sebagai gerakan sosial keagamaan yang beraqidahkan Islam. Hal itu tercemin dalam tujuannya "Menegakkan dan menjungjung tinggi Agama Islam, sehingga terwujud masyarakat utama, adil dan makmur, dirdhoi Allah SWT. ” Dan begitupun NU dengan tujuannya.

Dari rumusan tujuan tersebut, keduanya menempatkan Islam sebagai acuan cita idealnya, yang tidak mungkin diganggu gugat. Pendidikan yang bernaung di bawah panji kedua gerakan bukan semata-mata untuk membantu menumbuhkan mobilitas antar lapisan umat Islam atau masyarakat yang lebih luas, namun sekaligus sebagai cagar yang menjamin terselamatankannya struktur dan identitasnya dari generasi.

Sebagaimana dinyatakan oleh Cristoper J. Lucas, pendidikan itu adalah markas penyimpan kekuatan luar biasa. Yakni memiliki akses keseluruhan aspek kehidupan, memberi informasi yang paling berharga mengenai pegangan hidup masa depan serta membantu generasi dalam mempersiapkan kebutuhan esensialnya unutk menghadapi perubahan. ${ }^{11}$

Jika hal tersebut menjadi sikap umum dalam penyelenggaan tentang pendidikan Islam, baik oleh Muhammadiyah maupun oleh NU maka berarti tujuan esensial sebagaiman yang dikemukakan oleh Lucas tersebut, selama ini telah kurang mendapat tempat di lembaga-lembaga pendidikan islam di Indonesia.

\section{Berorientasi Kualitas bukan Populis}

Untuk melakukan reorientasi pada lembaga pendidikan Islam, perlu diarahakan pada pemberian ruang gerak yang seluasnyaseluasnya pada fungsi esensial dari pendidikan. Dalam arti pelaksanaan pendidikan bukan pada asas kepentingan mendapatkan popularitas ditengah masyarakat tetapi yang jauh lebih penting dari itu semua adalah bagaimana roh pendidikan dapat diintenalisasikan dalam diri insan akademik sehingga memiliki kualitas excelent untuk kemudian dapat bersaing di tengah kancah lokal maupun global. Sederhananya pendidikan bukan berbicara kwantitas tetapi kualitas.

Karena selama ini pendidikan diselenggarakan oleh pemerintah dan kebanyakan ormas adalah lebih kepada pemenuhan kebutuhan saja tanpa harus memikirkan output pada lembaga pendidikan tersebut. Sebagai bahan study kajian, ormas terbesar di Indonesia seperti NU dan Muhammadiyah yang sudah mendapatkan

${ }^{11}$ Ibid., 9 
Jurnal Ilmiah "Kreatif" Vol. XII No. 2 Juli 2015

"Jurnal Studi Pemikiran Pendidikan Agama Islam"

pengakuan public (public trust), harus mampu meningkatkan kualitas pelaksanaan pendidikan, baik itu dari segi kurikulum, manajemen pengelolaan, sarana dan prasarana yang mendukung jalannya kegiatan pendidikan. Dengan demikian lembaga pendidikan Muhammadiyah dan NU tidak lagi sekedar menikmati pengakuan peran kuntitatif yang diterima, baik dari masyarakat maupun pemerintah.

\section{Pendidikan Islam Perlu Pilot Project}

Untuk melakukan reorientasi pendidikan Muhammadiyah dan NU harus mampu membuat pilot project yang andal secara spiritual Islami, namun berwawasan keilmuan dan empirik. Sehingga bisa melahirkan hasil yang "hatinya dilimpahi suasana iman, dan di dalam pemikirannya melimpahi ilmu pengetahuan serta ditangannya tersimpan sejuta kecakapan."

Tampaknya pilot project semacam itu akan mendapat dukungan dari berbagai pihak. Apalagi kondisi politis maupun perekonomian pendukungnya sudah sangat memungkinkan. Namun, untuk merealisasikan perlu persiapan yang benar-benar matang. Terutama jika Pilot Project itu berskala internasional, seperti yang dilakukan oleh Muhammad Naquib Al-Attas melalui ISTAC di Malaysia yang didukung oleh kalangan Cendekiawan Muslim dan pemerintah setempat. Seperti membuat sebuah lembaga pendidikan yang memiliki haluan Islam modern.

Jumlah pendidikan Islam sekarang ini baik yang diselenggarakan oleh Muhammadiyah, NU maupun lembagalembaga lain, mulai dari TK, hingga perguruan tinggi sudah cukup besar. Karena itu sebelum memulai dengan pilot project perlu assessment. Hasilnya disebut feasibility study, mendesain perencanaan serta melakukan perencanan serta melakukan persiapan yang matang. Sebagai langkah awal bisa diambil Sekolah Menengah Umum (SMU) dan pergurun tunggi. Mengingat untuk jenis dan tingkat pendidikan ini perlu pembiayaan yang tidak sedikit. Pilot project ini juga memerlukan keberanian, karena mau tidak mau pilot project harus berbeda dengan yang telah ada dan terbatas dari ikataniktan formalitas yang sifatnya birokratis, seperti terpaku pada pada "pengakuan" dan "penghargaan".

\section{Kebijakan Pendidikan Nasional yang Mendukung}

Pendidikan Islam harus dilakukan upaya reformasi dari segala komponen baik itu dari segi sumber daya manusia (SDM), sistim manajemen maupun kurikulumnya. Reformasi filosofios dan nilai-nilai 
dasar pendidikan Islam sangat diperlukan sebagai dasar pembangunan pendidikan nasional yang secara konseptual dapat diterima oleh logika, secara cultural sesuai dengan budaya bangsa, dan secara politis dapat diterima oleh masyarakat luas.

Menurut Malik Fadjar dalam porses pendidikan setidaknya ada indikator yang dapat dilihat atau yang harus dicapai yang pertama adalah pendidikan akan berpengaruh pada perubahan masyarakat, dan kedua, pendidikan harus memberikan sumbangan optimal terhadap proses transformasi menuju terwujudnya masyarakat madani. ${ }^{12}$

Oleh sebab itu beberapa kaidah mendasar dapat dikaji untuk merumuskan kebijakan-kebijakan pendidikan nasional dalam kerangka keterpaduan antar pendidikan umum dengan pendidikan Islam agar sesuai dengan arah dan cita pendidikan:

1. Pembangunan manusia seutuhnya, termasuk pengembangan kemampuan untuk menyesuaikan diri dengan perubahan yang tengah berlangsung amat cepat,

2. Penumbuhan pendidikan masyarakat yang dapat menumbuhkan perspektif historis yaitu kesadaran akan nilai-nilai diyakini sangat dibutuhkan dalam tatanan kehidupan masyarakat baru Indonesia,

3. Pembangunan pendidikan misal melalui pemberdayaan dan penggunaan media komunikasi cetak dan elektronik. ${ }^{13}$

\section{Sintesa Antara Perguruan Tinggi dan Pesantren}

Harus diakui memang bahwa output yang dihasilkan lembaga perguruan tinggi memang memiliki kemampuan yang cukup memadai, namun dari segi aspek moral masih sangat jauh dari nilai-nilai agama, hukum, dan kesusilaan. Di lembaga perguran tinggi banyak menghasilkan intelektual yang liberal, sekuler dan lain-lain. Demoralisasi justru terjadi dan ini banyak terjadi lembaga pendidikan tinggi.

Sementara pesantren, dari segi kepemimpinannya masih bersikukuh dengan pola kepemimpinan yang sentralisrtik dan hirarkis yang berpusat pada seorang kiai. Hal ini disebabkan karena ihwal pendirian pesantren adalah biasanya atas usaha pribadi seorang kiai.

Seperti yang diketahui, pesantren mempunyai tradisi yang kuat dari segi transmisi keilmuan klasik. Namun karena kurangnya improfisasi metodologis, proses transmisi tersebut hanya melahirkan penumpukan keilmuan. ${ }^{14}$

\footnotetext{
${ }^{12}$ Abdul Malik Fadjar, Holistika Pemikiran Pendidikan ..., 113

${ }^{13}$ Ibid., 151

${ }^{14}$ Abdul Malik Fadjar, Reorientasi Perguruan Islam..., 155
} 
Jurnal Ilmiah "Kreatif" Vol. XII No. 2 Juli 2015

"Jurnal Studi Pemikiran Pendidikan Agama Islam"

Selain itu penyelenggaraan pendidikan di pesantern terjadi disorientasi, yakni pesantren kehilangan kemampuan mendefinisikan dan memposisikan dirinya ditengah perubahan sosial yang begitu cepat. Dalam konteks perubahan ini pesantren menghadapi dilema antara keharusan mempertahankan jati dirinya dalam kebutuhan menyerap budaya baru yang datang dari luar pesantren. ${ }^{15}$

Agar terjadinya perpaduan antara pendidikan islam dengan pendidikan umum maka harus dilakukan sintesa (penyatuan) atau konvergensi pesantren dan perguruan tinggi, akhir-akhir ini dapat dipandang sebagai perkembangan yang konstruktif. Di beberapa kota mulai didirikan pesantren yang bernuansa perguruan tinggi, meskipun di dalamnya tidak ada jenis pendidikan yang secara formal disebut perguruan tinggi.

Di Surakarta misalnya, terdapat pondok Hajjah Nuriyah Shabran yang didirikan oleh Universitas Muhammadiyah Surakarta. Di Malang terdapat pondok Pesantren Al-Hikam yang santrinya dari kalangan mahasiswa. yang menarik lagi adalah ide CIDES (Centre for Information and Devolopment Students) tentang pendirian Pesantren Politeknik. Perkembangan lainya yang juga perlu dicermati adalah pertumbuhan pesantren kilat (sanlat) yang sekarang sudah menjadi trend di berbagai kota besar di Indonesia.

Pendidikan Islam tidak hanya pada penyatuan antara pendidikan umum dengan pendidikan Islam, tapi pembaruan pendidikan harus dilakukan perubahan secara komprehensif dan sistimatis. ${ }^{16}$ Ada beberapa point penting yang harus diupayakan dalam melakukan pembaruan pendidikan Islam atau yang biasa disebut sebagai defensive strategy tentang pembaruan pendidikan Islam:

1. Melaksanakan Otonomi dan Desntralisasi

Dulu pengendalian pelaksanaan pendidikan ditangani oleh pemerintah pusat yaitu bersifat setralistik baik itu dari segi konsolidasi, penentuan kebijakan, pembinaan kelembagaan, pengambilan keputusan, koordinasi. Sekarang yang menjadi subyek pelaksaan pendidikan harus berada pada pengendalian daerah (otonomi) yang akan mnentukan seluruh gerak langkah praktik pendidikan di daerah masing-masing. Dengan demikian pengelolaan siswa dalam masalah keagamaan bisa dilakukan secara maksimal baik pada waktu pelajaran maupun di luar. Pengembangan pendidikan itu semua tergantung pada keadaan lokalitas masingmasing tanpa harus keluar dari koridor tujuan pendidikan nasional.

\footnotetext{
${ }^{15}$ Ibid., 116

${ }^{16}$ Abdul Malik Fadjar, Holistika Pemikiran Pendidikan ...,73
} 
Jurnal Ilmiah "Kreatif" Vol. XII No. 2 Juli 2015

"Jurnal Studi Pemikiran Pendidikan Agama Islam"

2. Manejemen Berbasis Sekolah (MBS-School Based Management)

Pemberdayaaan pendidikan disamping untuk memenuhi tuntan desentralisai, juga di tunjukan sebagai sarana efisiensi dalam mendistribusikan anggaran pendidikan. Reformasi dalam pengelolaan pendidikan diarahkan pada terciptanya kondisi yang desetralistik baik tatanan birokrasi maupun pengeloalaan sekolah.

Menurut A. Malik Fadjar MBS ini di lakukan dalam rangka memberikan kesempatan atau ruang bagi sekolah untuk mengatur pola pembelajaran dalam sekolah itu sendiri, sehingga keterpaduan antara pendidikan umum dengan pendidikan Islam dapat tercapai. ${ }^{17}$

3. Pembinaan Perguruan Tinggi yang Bersifat Kontinue

Isu-isu stratergis menyangkut pembinaan pendidikan tinggi dalam rangka meningkatkan peran sertanya dalam menunjang pembangunan Islam, antara lain mencakup; konsolidasi dan adaptasi kelembagaan, perluas askes yang dikemas dalam konteks peningkatan dan penjamin mutu, dan iternasionalisasi. Tiga hal tersebut harus dijabarkan dalam konteks dalam program-program dan agenda aksi yang konkrit di perguruan tinggi sesuai dengan konteks institusionalnya.

4. Metodologi Pendidikan Agama Islam di Sekolah

Pendidikan Islam bukan sekedar mengalihkan pengetahuan dan keterampilan (sebagai isi pendidikannya) melainkan lebih merupakan suatu ikhtiar untuk "menggugah fitrah insaniah" (to stir up certain innate power), sehingga pesrta didik bisa menjadi penganut atau pemeluk agama yang taat dan baik.

Lebih dari itu, pendidikan agama Islam bukan merupakan kegiatan yang terpisah dari aspek kehidupan masyarakat luas. Ia berlangsung dalam konteks keselarasan maupun keseimbangan dengan kegiatan lain, baik program perorangan maupun kelembagaan, dan posisi yang saling memperkokoh antara yang satu dengan yang lain.

Selain dari itu, pelaksaan pendidikan agama Islam di sekolah memerlukan suasana interaksi antara guru dan peserta didik yang sifatnya lebih mendalam, lahir dan batin. Figure guru agama bukan saja sekedar "penyampai" materi pelajaran, tetapi lebih dari itu adalah sebagai "sumber spiritual" dan sekaligus sebagai "pembimbing". ${ }^{18}$

17 Abdul Malik Fadjar (2001), Platform Reformasi Pendidikan dan Pengembangan Sumber Daya Manusia. Jakarta; PT.Logos Wacana Ilmu, 50

${ }^{18}$ Abdul Malik Fadjar, Holistika Pemikiran Pendidikan ..., 195-196 
Jurnal Ilmiah "Kreatif" Vol. XII No. 2 Juli 2015

"Jurnal Studi Pemikiran Pendidikan Agama Islam"

Mutu maupun pencapaian pendidikan Islam perlu diorientasikan kepada hal-hal sebagai berikut:

a. Tercapainya sasaran kualitas pribadi, baik sebagai manusia yang beragama maupun sebagai Indonesia yang ciri-cirinya dijadikan sebagai tujuan pendidikan nasional.

b. Integrasi pendidikan agama dengan keseluruhan proses maupun institusi pendidikan yang lain.

c. Menginternalisasikan nilai-nilai Islam dalam sistim sosial.

d. Penyadaran pribadi akan tuntutan hari depannya dan transformasi social budaya yang terus berlangsung.

e. Dan Pembentukan wawasan ijtihadiyah (cerdas rasional). ${ }^{19}$

\section{Simpulan}

Secara umum pengembangan pendidikan Islam dapat diklasifikasikan pada dua dimensi, yaitu; Pertama, berupaya mengembangkan ajaran Islam lewat instutisi pendidikan umum. Kedua berusaha menciptakan generasi yang anggun secara akhlak dan unggul secara intektual dan mengajak umat Islam untuk keluar dari jaring pemikiran tradisional melalui reinterpretasi terhadap doktrin Islam dalam rumusan dan penjelasan yang dapat diterima oleh rasio. Ide-ide pengembangan dan pembaruan tersebut hanya dapat dilaksanakan melalui pendidikan. Pendidikan juga merupakan upaya strategis untuk menyelamatkan umat Islam dari pola berpikir yang statis menuju pemikiran yang dinamis.

Pendidikan yang dimaksud harus kembali menjadikan Islam sebagai panji dan acuan cita ideal pendidikan Islam modern. Maksudnya adalah menggabungkan sistem pendidikan umum dengan sistem pendidikan tradisonalisme Islam secara integral, yang dalam pelaksanaanya hendaknya didasarkan pada landasan yang kokoh yaitu Al-Qur'an dan Al-Hadits.

Landasan ini merupakan kerangka filosofis untuk merumuskan konsep dan tujuan ideal pendidikan Islam, baik secara vertikal (khaliq) maupun horizontal (makhluk). Dalam pandangan Islam, paling tidak ada dua sisi tugas penciptaan manusia, yaitu sebagai abdi Allah dan khalifah fi al-ardh. Dalam proses kejadiannya, manusia diberikan Allah al-ruh dan al-`aql. Untuk itu, media yang dapat mengembangkan potensi al-ruh untuk menalar penunjuk pelaksanaan ketundukan dan kepatuhan manusia kepada Khaliqnya. Di sini eksistensi akal merupakan potensi dasar bagi peserta didik yang perlu dipelihara

19 Ibid, 
Jurnal Ilmiah "Kreatif" Vol. XII No. 2 Juli 2015

"Jurnal Studi Pemikiran Pendidikan Agama Islam"

dan dikembangkan guna menyusun kerangka teoritis dan metodologis bagaimana menata hubungan yang harmonis secara vertikal maupun horizontal dalam konteks tujuan penciptannya.

Batasan di atas memberikan arti, bahwa dalam epistemologi pendidikan Islam, ilmu pengetahuan dapat diperoleh apabila peserta didik (manusia) mendayagunakan berbagai media, baik yang diperoleh melalui persepsi inderawi, akal, qalbu, wahyu maupun ilham. Oleh karena itu, aktivitas pendidikan dalam Islam hendaknya memberikan kemungkinan yang sebesar-besarnya bagi pengembangan ke semua dimensi tersebut. Pengembangan tersebut merupakan proses integrasi ruh dan jasad. Konsep ini diketengahkannya dengan menggariskan perlunya pengkajian ilmu pengtahuan secara langsung, sesuai prinsipprinsip Al-Qur'an dan Al-Hadits, bukan semata-mata dari kitab tertentu.

Pendidikan Islam hendaknya diarahkan pada usaha membentuk manusia muslim yang berbudi pekerti luhur, alim dalam agama, luas pandangan dan paham masalah ilmu keduniaan, serta bersedia berjuang untuk kemajuan masyarakatnya. Caranya adalah dengan merumuskan pilot project, agar arah dan target pendidikan Islam dapat tercapai Hal ini berarti bahwa pendidikan Islam merupakan upaya pembinaan pribadi muslim sejati yang bertaqwa, baik sebagai 'abdi maupun khalifah fi al-ardh. Untuk mencapai tujuan ini, proses pendidikan Islam hendaknya mengakomodasi berbagai ilmu pengetahuan yang ada.

\section{Daftar Pustaka}

Azra, Azyumardi, 2000. Pendidikan Islam-Tradisi dan Modernisasi Menuju Milenium Baru. Jakarta; Logos Wacana Ilmu.

Fadjar, Malik, 2005. Holistika Pemikiran Pendidikan. Jakarta: PT.Raja Grafindo Persada.

2009. Pergumulan Pemikiran Pendidikan Tinggi Islam. Malang: UMMPRESS.

----------, ddk,2001. Platform Reformasi Pendidikan dan Pengembangan Sumber Daya Manusia. Jakarta; PT.Logos Wacana Ilmu.

1999. Reorientasi Pendidikan Islam. Jakarta; Fadjar Dunia

--------, dkk, 1995. Embrio Cendekiawan Muhammadiyah. Jakarta;PERKASA PRESS.

, Ridwan, 2009. Islam Kontekstual Pertautan Dialektis dengan

Konteks. Yogyakarta: Grafindo Litera Media. 
Jurnal IImiah "Kreatif" Vol. XII No. 2 Juli 2015

"Jurnal Studi Pemikiran Pendidikan Agama Islam"

Munir Mulkham, Menggagas Pesantren Masa Depan, Qolam Yogyakarta; 2003

Hudijono, Anwar dan Thayib, Anshari, 2009. Darah Guru Darah Muhammadiyah. Malang; UMMPRESS. 